\title{
SEBARAN KUALITAS AIR PANTAI UTARA JAKARTA PASCA REKLAMASI DI PERAIRAN TELUK JAKARTA
}

\section{THE DISTRIBUTION OF WATER QUALITY POST RECLAMATION CONDITION IN THE NORTH COAST OF JAKARTA BAY}

\author{
Anma Hari Kusuma ${ }^{1}$ \\ ${ }^{1}$ Program Studi Ilmu Kelautan, Universitas Lampung \\ Korespondensi: anmakelautan@gmail.com
}

\begin{abstract}
Jakarta Bay is a region directly affected by many activities of the metropolitan city DKI Jakarta so that becomes meet the place from many various pollutant compounds from DKI Jakarta. Reclamation activities also contribute to add burden on the Jakarta Bay. The purpose of this study is to explain the current condition of the waters through the distribution of water quality in North Coast Jakarta after reclamation activities. This research was conducted by to compare condition of water quality in October 2018 during after reclamation activity with previous research water quality in September 2014 before the reclamation activity in Jakarta Bay. This results showed temperature conditions is $28-31^{\circ} \mathrm{C}$, salinity is $25,42-35 \mathrm{psu}$, acidity $(\mathrm{pH})$ is $7,2-8,6$, total suspended solid (TSS) is $1-216 \mathrm{mg} / 1$, Dissolved Copper $(\mathrm{Cu})$ is $0-0,092 \mathrm{mg} / \mathrm{l}$, and Zinc $(\mathrm{Zn})$ is $0-0,280 \mathrm{mg} / \mathrm{l}$. While previous research at pre-recalamation showed temperature conditions is $28,9-30^{\circ} \mathrm{C}$, salinity is $29,5-30,6 \mathrm{psu}$, acidity $(\mathrm{pH})$ is 7,8-8,1, total suspended solid (TSS) is $25-68 \mathrm{mg} / 1$, Dissolved Copper $(\mathrm{Cu})$ is $0,001-0,005 \mathrm{mg} / \mathrm{l}$, and Zinc $(\mathrm{Zn})$ is $0,003-0,097 \mathrm{mg} / \mathrm{l}$. There is artificial islands causes the supply of material from the land into the sea to be retained in the coastal area and reduce the current speed so that there is a decrease in the ability of flushing time and the water quality concentrated in the coastal area continuously. Finally, this condition results concentration of water quality at post-reclamation more high than before the prereclamation in Jakarta Bay.
\end{abstract}

Keywords: flushing time, increase consentration, Jakarta Bay, water quality

\section{ABSTRAK}

Teluk Jakarta merupakan kawasan yang terkena dampak langsung dari berbagai aktivitas kota metropolitan DKI Jakarta sehingga menjadi tempat bermuaranya berbagai senyawa polutan di wilayah DKI Jakarta. Adanya kegiatan reklamasi juga turut menambah beban Teluk Jakarta. Tujuan dari penelitian ini adalah menjelaskan kondisi terkini perairan Teluk Jakarta melalui sebaran kualitas air pasca kegiatan reklamasi. Penelitian ini dilakukan dengan membandingkan data kualitas air pada bulan Oktober 2018 dimana saat pasca reklamasi dengan penelitian kualitas air sebelumnya pada bulan September 2014 pada saat sebelum adanya kegiatan reklamasi di Teluk Jakarta. Hasil penelitian ini menunjukkan kondisi suhu berkisar $28-31{ }^{\circ} \mathrm{C}$, salinitas berkisar 25,42-35 psu, derajat keasaman $(\mathrm{pH})$ berkisar 7,2-8,6, partikel tersuspensi (TSS) berkisar 1-216 mg/1, Cu Terlarut berkisar 0-0,092 mg/l, dan Zn berkisar 0-0,280 mg/l. Sedangkan penelitian pada sebelumnya pada saat pra-reklamasi menunjukkan suhu berkisar $28,9-30{ }^{\circ} \mathrm{C}$, salinitas berkisar $29,5-30,6$ psu, derajat keasaman $(\mathrm{pH})$ berkisar 7,80-8,17, partikel tersuspensi (TSS) berkisar 25-68 mg/l, Cu berkisar 0,001$0,005 \mathrm{mg} / \mathrm{l}$, dan Zn berkisar 0,003-0,097 mg/l. Adanya pulau buatan mengakibatkan pasokan material dari daratan yang masuk ke laut menjadi tertahan di wilayah pesisir dan mengurangi kecepatan arus sehingga terjadi penurunan kemampuan waktu pencucian dan kualitas perairan terkonsentrasi di wilayah pesisir secara terus menerus. Kondisi ini pada akhirnya mengakibatkan konsentrasi kualitas perairan pada saat pasca reklamasi lebih tinggi dibandingkan pada saat sebelum adanya kegiatan reklamasi di Teluk Jakarta.

Kata kunci: kualitas air, peningkatan konsentrasi, Teluk Jakarta, waktu pencucian 


\section{PENDAHULUAN}

Teluk Jakarta merupakan wilayah yang terkena dampak langsung dari berbagai aktivitas kota metropolitan DKI Jakarta karena menjadi tempat bermuaranya berbagai senyawa pencemar dari 13 sungai yang mengalir di DKI Jakarta seperti Sungai Angke, S.Mookervaart, S.Grogol, S.Pesanggrahan, S.Krukut, S.Kalibaru Barat, S.Ciliwung, S.Kalibaru Timur, S.Cipinang, S.Sunter, S.Buaran, S.Jatikramat, dan S.Cakung. Melalui sungai-sungai ini limbah bahan pencemar dari hasil berbagai aktivitas manusia seperti pemukiman, industri, dan percetakan mengalir ke Teluk Jakarta. Teluk Jakarta juga merupakan tempat lalu lintas kapal yang sangat padat. Selain itu, adanya berbagai aktivitas di kawasan pesisir menambah tekanan terhadap Teluk Jakarta. Adanya berbagai tekanan terhadap Teluk Jakarta sangat kemungkinan bahwa kondisi perairan Teluk Jakarta mengalami degradasi. Berbagai kasus banyak terjadi di Teluk Jakarta seperti ledakan populasi alga berbahaya (HABS) (Prayitno 2011), kontaminasi logam berat (Cordova dan Riani 2011), akumulasi logam berat pada kerang hijau (Jalius et al. 2008), pencemaran pestisida (Prartono et al. 2009) dan tingginya kandungan senyawa Polisiklik Aromatik Hidrokarbon (PAH) (Ahmad 2012). Selain itu, saat ini terdapat pulau buatan dari kegiatan reklamasi turut menambah beban Teluk Jakarta.

Adanya aktivitas reklamasi Teluk Jakarta turut menambah beban sehingga mengakibatkan dampak perubahan lingkungan seperti penurunan kecepatan arus permukaan dan penambahan waktu pencucian (flushing time) perairan (Pranowo et al. 2014), peningkatan material tersuspensi (Aprilia dan Pratomo 2017), peningkatan material tersuspensi dan pendangkalan yang diakibatkan oleh aktivitas pengerukan (Wiryawan et al. 2013). Penelitian ini memberikan gambaran dan penjelasan lebih lanjut mengenai kondisi Teluk Jakarta pasca kegiatan reklamasi Teluk Jakarta. Tujuan dari penelitian ini adalah menjelaskan kondisi terkini perairan Teluk Jakarta melalui pola distribusi kualitas perairan pasca kegiatan reklamasi yang dibandingkan dengan pola distribusi kualitas perairan dari penelitian sebelumnya pada saat sebelum adanya reklamasi sehingga dapat digunakan bagi perencanaan, pengelolaan, dan pengkajian wilayah pesisir dan laut secara spesifik dan berkelanjutan oleh pihak yang berkepentingan.

\section{METODE PENELITIAN}

Penelitian ini dilakukan dari bulan April-Oktober 2018. Lokasi penelitian dilakukan di Teluk Jakarta. Alat yang dipakai dalam penelitian ini diantaranya adalah Global Positioning System (GPS), Van Dorn Water Sampler, termometer, refraktometer, pH-meter, oven, desikator, dan vakum pump. Sedangkan bahan yang dipakai dalam penelitian ini diantaranya adalah akuades, botol polietilen, larutan APDC, larutan $\mathrm{HNO}_{3}$ dan larutan MIBK. Pengukuran mengenai parameter kualitas perairan seperti suhu, salinitas, derajat keasaman $(\mathrm{pH})$ dilakukan secara in situ sedangkan parameter seperti material tersuspensi (TSS) dan logam berat terlarut dilakukan dengan pengambilan contoh air laut in situ dan dianalisis lebih lanjut di laboratorium. Peta lokasi penelitian dapat dilihat pada Gambar 1 .

\section{Pengukuran parameter fisika-kimia perairan}

Pengukuran mengenai parameter fisika-kimia perairan dilakukan secara in situ meliputi suhu menggunakan termometer, salinitas menggunakan refraktometer, derajat keasaman $(\mathrm{pH})$ menggunakan $\mathrm{pH}-$ meter. Sedangkan parameter material tersuspensi (TSS) dan logam berat terlarut dilakukan dengan pengambilan contoh air laut in situ dan di analisis lebih lanjut di laboratorium.

\section{Pengambilan contoh air laut}

Contoh air laut diambil menggunakan Van Dorn Water Sampler dengan volume 2 liter yang terbuat dari bahan Poly Vinyl Clorida (PVC). Contoh air laut dimasukkan ke dalam botol polyetilen bersih sesuai standar (APHA 2012) dengan volume 1 liter dan disimpan di dalam kotak es selama proses transportasi menuju laboratorium untuk dilakukan analisis lebih lanjut.

\section{Analisis partikel tersuspensi (TSS)}

Analisis partikel tersuspensi (TSS) mengikuti prosedur APHA (2012) yang 
secara singkat diuraikan sebagai berikut. Contoh air laut sebanyak $100 \mathrm{ml}$ disaring menggunakan filter selulosa dengan ukuran 0,45 (bersih, kering, dan ditimbang berat awal). Filter selulosa hasil penyaringan selanjutnya dikeringkan dalam oven $103{ }^{\circ} \mathrm{C}$ sampai $105{ }^{\circ} \mathrm{C}$ selama 1 jam. Filter selulosa didinginkan dalam desikator dan ditimbang untuk didapatkan berat akhir.

\section{Analisis logam berat terlarut}

Analisis logam berat terlarut juga mengikuti prosedur APHA (2012) yang secara singkat diuraikan sebagai berikut. Contoh air laut sebanyak $250 \mathrm{ml}$ disaring menggunakan filter selulosa dengan ukuran 0,45 $\mu \mathrm{m}$ dan selanjutnya ditambahkan asam nitrat $\left(\mathrm{HNO}_{3}\right)$ pekat sampai $\mathrm{pH}<2$ lalu diekstraksi dengan $5 \mathrm{ml}$ APDC dan 25 ml MIBK. Hasil ekstraksi dalam fase organik selanjutnya dilarutkan kembali dengan menambahkan $2 \mathrm{ml}$ asam nitrat $\left(\mathrm{HNO}_{3}\right)$ pekat sehingga terbentuk ion logam yang larut dalam fase air. Kadar logam berat di ukur nilainya dengan mengguankan $A A S$ Pin Aacle $900 \mathrm{H}$ dengan deteksi limit 0,001 ppm.

\section{Analisis data}

Analisis data dilakukan dengan membandingkan data pola distribusi kualitas perairan seperti suhu, salinitas, derajat keasaman $(\mathrm{pH})$, partikel tersuspensi, dan logam berat terlarut pada saat pascareklamasi dengan data pola distribusi kualitas perairan pada penelitian sebelumnya pada saat pra-reklamasi di Teluk Jakarta. Selanjutnya perbedaan pola distribusi kualitas perairan di Teluk Jakarta antara tersebut antara pada saat pasca-reklamasi dengan pada saaat pra-reklamasi dikaitkan dengan data pola distribusi dan sirkulasi arus antara pada saat pra-rekalamsi dengan pasca-reklamasi di Teluk Jakarta.

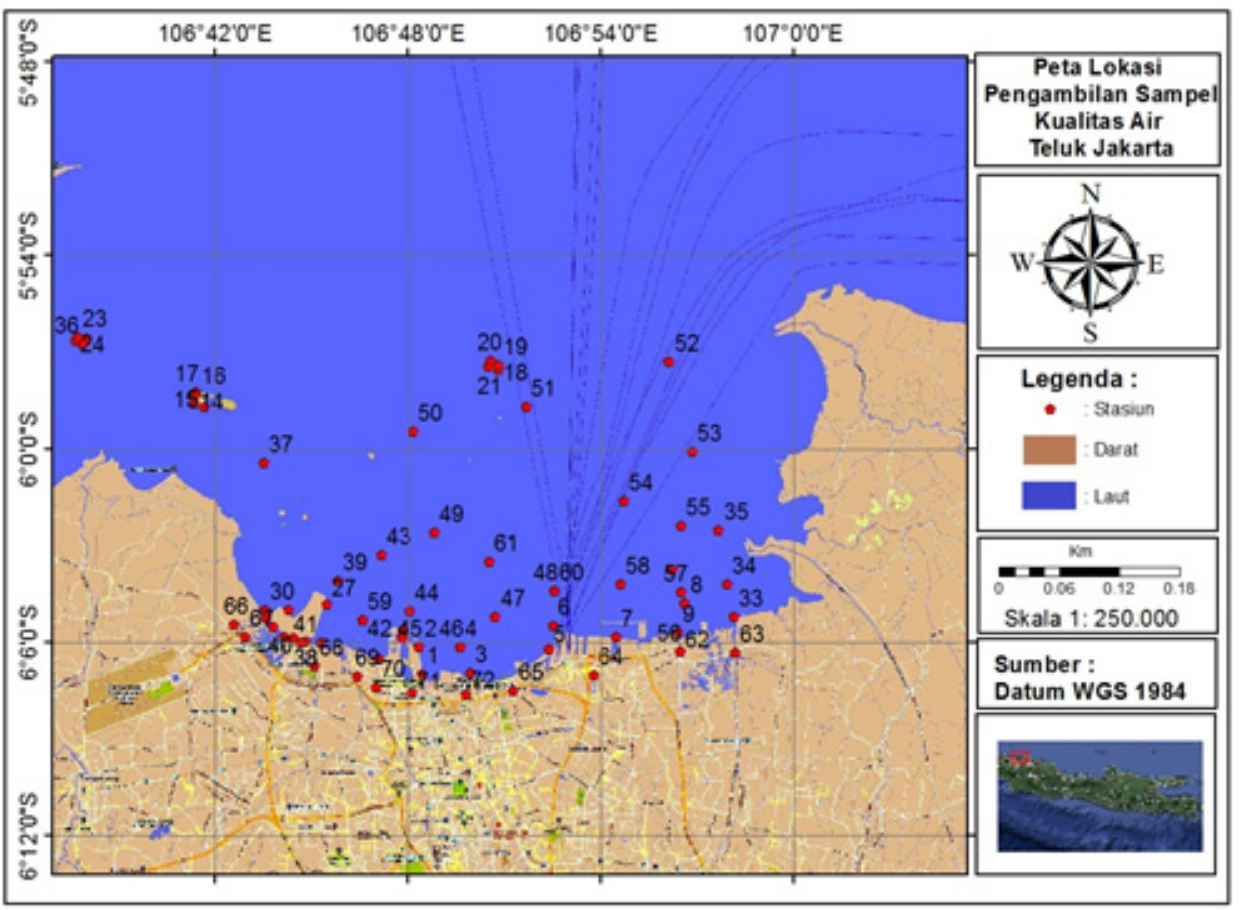

Gambar 1. Peta lokasi penelitian 


\section{HASIL DAN PEMBAHASAN}

\section{Sebaran fisika-kimia perairan Teluk Jakarta}

Suhu pada saat pasca reklamasi berkisar antara $28-31{ }^{\circ} \mathrm{C}$ dengan rata-rata sebesar $29{ }^{\circ} \mathrm{C}$ (Gambar 2a) sedangkan pada saat pra-reklamasi berkisar antara 28,9$30,2{ }^{\circ} \mathrm{C}$ dengan rata-rata sebesar $29,35{ }^{\circ} \mathrm{C}$ (Gambar 2b). Suhu perairan Teluk Jakarta berkisar 28,9-31,2 ${ }^{\circ} \mathrm{C}$ (Ilahude 1995; Williams et al. 2000; Paonganan et al. 2005; Hadikusumah 2008; Kusuma et al. 2014). Suhu berkaitan dengan kapasitas bahang dalam suatu perairan. Suhu berkaitan dengan aktivitas metabolisme organisme akuatik dimana peningkatan suhu sebesar $10{ }^{\circ} \mathrm{C}$ menyebabkan terjadinya peningkatan konsumsi oksigen sekitar 2-3 kali lipat yang disertai peningkatan aktivitas dekomposisi bahan organik oleh mikroba (Effendi 2003). Umumnya suhu di perairan laut sebesar 28-30 ${ }^{\circ} \mathrm{C}$ (KLHK 2004). Suhu di perairan Teluk Jakarta tidak lepas dari pengaruh Laut Jawa yang mengalami peningkatan yang mencapai puncaknya pada bulan Maret-Mei dan bulan September-November karena pada ke dua bulan ini tiupan angin relatif lemah dan memiliki konsistensi arah yang labil sehingga pemanasan lebih maksimal (Syahdan 2015). Ilahude (1995) menambahkan nilai maksimum di Teluk Jakarta terjadi pada bulan Februari karena tiupan yang cukup keras dan minimum bulan Agustus yang disebabkan oleh penguapan yang relatif tinggi.

Salinitas berkisar pada saat pasca reklamasi 0-35 psu dengan rata-rata sebesar 25,42 psu (Gambar 2c) sedangkan pada saat pra-reklamasi salinitas berkisar antara 29,5-30,6 psu dengan rata-rata sebesar 30,22 psu (Gambar 2d). Salinitas perairan Teluk Jakarta berkisar 22-32,4 psu (Praseno dan Kastoro 1979; Ilahude 1995; Mezuan 2007; Sutisna 2007; Hadikusumah 2008; Kusuma et al. 2014). Salinitas berkaitan dengan jumlah garam terlarut yang terkandung dalam satu kilogram air laut dimana dianggap semua karbonat telah diubah menjadi oksida dan unsur Bromida (Br), Iodium (I) diganti oleh Klorida $(\mathrm{Cl})$ dan semua bahan organik telah dioksidasi secara sempurna. Umumnya salinitas di perairan laut sebesar 33-34 psu (KLHK 2004). Salinitas di perairan Teluk
Jakarta juga tidak lepas dari pengaruh Laut Jawa yang mengalami minimum pada bulan Februari dan maksimum September (Ilahude 1995). Salinitas minimum terjadi pada bulan Februari dan salinitas maksimum pada bulan September. Hal ini dikarenakan pada bulan Januari-Februari massa air dari Laut Natuna melewati Selat Karimata memasuki Laut Jawa dari arah barat yang dalam perjalannya banyak mengalami pengenceran dari aliran-aliran sungai disekitarnya. Sedangkan pada bulan September-November, massa air bersalinitas tinggi dari Laut Flores dan Selat Makassar masuk ke Laut Jawa. Dampak dari reklamasi Teluk Jakarta hanya sedikit terlihat dari pola sebaran suhu dan salinitas dimana menggambarkan nilai kisaran salinitas setelah pasca reklamasi lebih besar dibandingkan pra-reklamasi. Adanya aktivitas reklamasi mengakibatkan perubahan suhu dan salinitas Teluk Jakarta. Adanya pulau reklamasi membuat pelemahan arus ditandai dengan penurunan intensitas energi kinetik. Terjadinya peningkatan kisaran nilai salinitas pasca reklamasi adanya massa air yang menumpuk dimana massa air sulit bergerak keluar akibat adanya pulau reklamasi seiring dengan proses penguapan oleh radiasi matahari.

Derajat keasaman $(\mathrm{pH})$ pada saat pasca reklamasi berkisar 7,2-8,6 dengan rata-rata sebesar 8,10 (Gambar 2e) sedangkan pada saat pra-reklamasi derajat keasaman berkisar antara 7,8-8,17 dengan rata-rata sebesar 8,02 (Gambar 2f). Derajat keasaman $(\mathrm{pH})$ perairan Teluk Jakarta berkisar 6.5-8.1 (Praseno dan Kastoro 1979; Williams et al. 2000; Paonganan et al. 2005; Sutisna 2007; BPLHD 2010; Kusuma et al. 2014). Derajat keasaman (pH) berkaitan dengan jumlah ion hidrogen $\left(\mathrm{H}^{+}\right)$ yang dinyatakan logaritmik dalam suatu perairan. Umumnya derajat keasaman $(\mathrm{pH})$ di perairan laut sebesar 7-8,5 (KLHK 2004). Pola distribusi suhu, salintas dan derajat keasaman $(\mathrm{pH})$ baik pada saat pra-reklamasi maupun pasca reklamasi menjelaskan bahwa pengaruh pasokan input meterial dari daratan memegang peranan sangat penting di Teluk Jakarta. Sebaran suhu, salinitas dan derajat keasaman $(\mathrm{pH})$ pada saat pasca reklamasi dan pra-reklamasi di Teluk Jakarta dapat dilihat pada Gambar 2. 


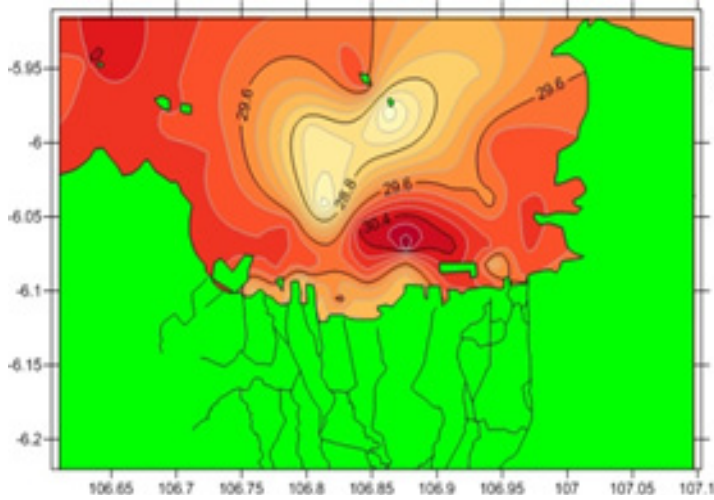

(a)

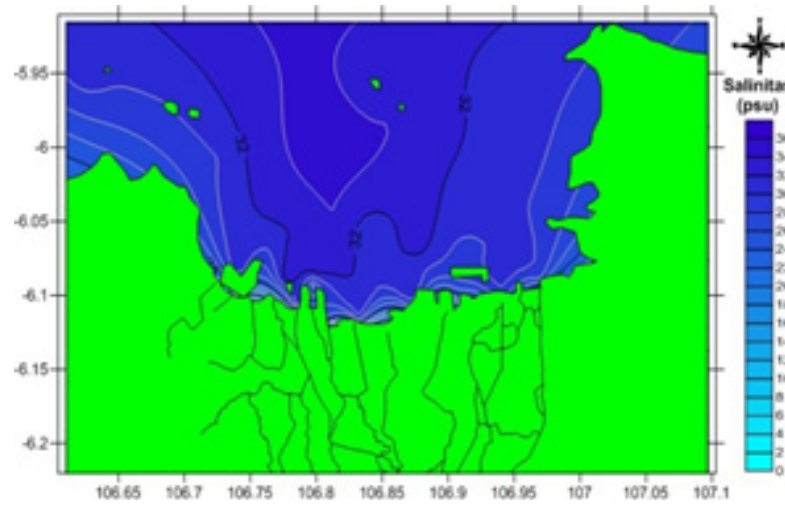

(c)

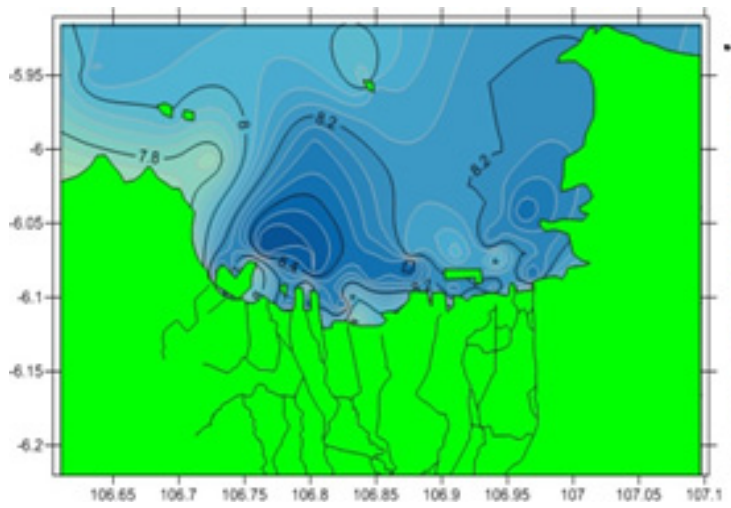

(e)

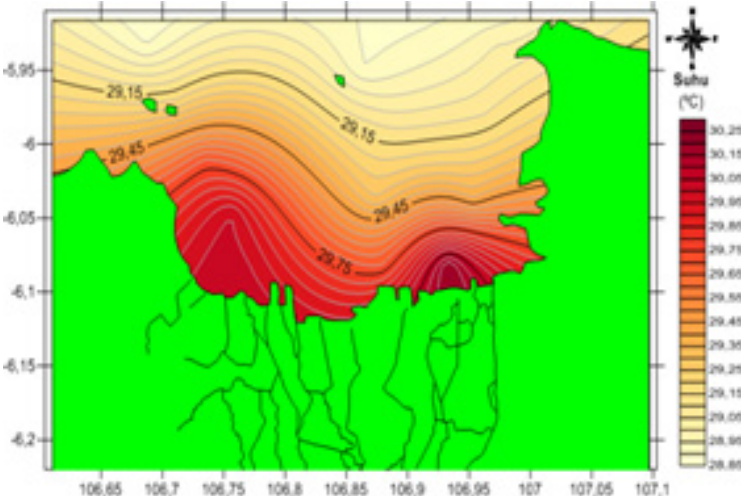

(b)

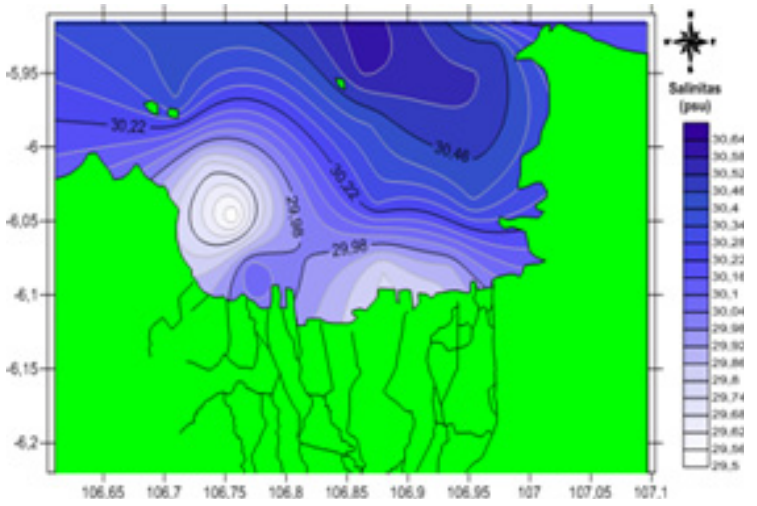

(d)

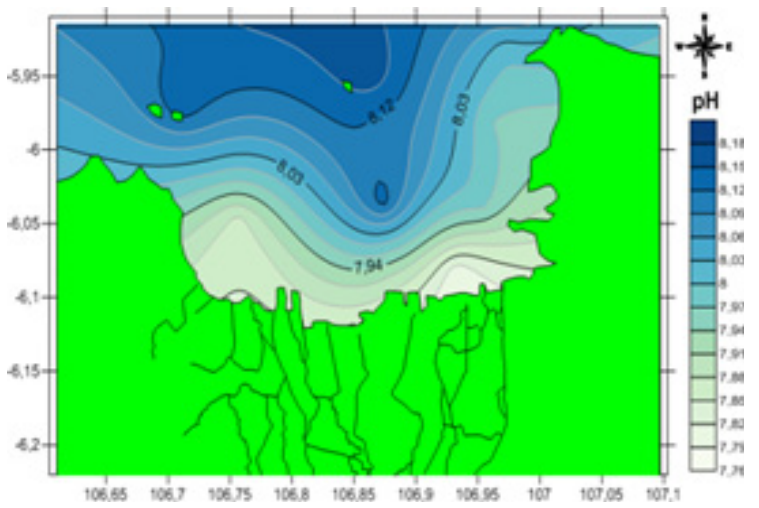

(f)

Gambar 2. Sebaran (a) suhu, (c) salinitas, dan (e) derajat keasaman (pH) pada saat pasca reklamasi sedangkan sebaran (b) suhu, (d) salinitas, dan (f) derajat keasaman $(\mathrm{pH})$ pada saat pre-reklamasi di Teluk Jakarta

Partikel tersuspensi (TSS) permukaan pada saat pasca reklamasi berkisar 1-216 $\mathrm{mg} / 1$ dengan rata-rata sebesar 33,27 mg/1 (Gambar 3a) sedangkan pada saat pra-reklamasi berkisar antara 25-68 mg/1 dengan rata-rata sebesar 54,27 mg/1 (Gambar 3b). Partikel tersuspensi (TSS) perairan Teluk Jakarta berkisar 5-45,2 mg/1 (Pemda DKI 1999; Mezuan 2007; Sutisna 2007; Kusuma et al. 2014). Umumnya nilai partikel tersuspensi (TSS) di perairan laut sebesar $20 \mathrm{mg} / 1$ (KLHK
2004). Partikel tersuspensi (TSS) di Teluk Jakarta didominasi oleh pasokan material yang dibawa dari aktivitas antropogenik di daratan yang dibawa oleh aliran sungai dan udara serta dari reklamasi Teluk Jakarta. Partikel tersuspensi (TSS) dalam jumlah yang tinggi dapat mengakibatkan terganggunya sistem osmoregulasi, pernapasan dan daya lihat organisme akuatik serta menghambat penetrasi cahaya ke perairan dan aktivitas fotosintesis. Aktivitas reklamasi juga mengakibatkan perubahan kondisi sebaran 
kekeruhan dan partikel tersuspensi di Teluk Jakarta. Wiryawan et al. (2013) mengatakan aktivitas reklamasi di Teluk Jakarta mengakitbatkan meningkatnya nilai konsentrasi dan partikel tersuspensi (TSS) yang berujung pada pendangkalan alur lalu lintas pelayaran laut sehingga perlu dilakukan upaya pengerukan. Aprilia dan Partomo (2017) mengatakan nilai konsentrasi sedimen tersuspensi $0-0,11$ $\mathrm{mg} / 1$ pada bulan Januari 2011, 0-0,02 $\mathrm{mg} / 1$ pada bulan September 2011 namun setelah adanya reklamasi nilai konsentrasi sedimen tersuspensi $0-0,032 \mathrm{mg} / 1$ pada bulan Februari 2016, 0-0,256 mg/1 pada bulan Mei 2016. Wilayah yang mengalami peningkatan konsentrasi partikel tersuspensi (TSS) adalah bagian muara sungai dan di beberapa lokasi sekitar pulau buatan dari kegiatan reklamasi. Dampak dari reklamasi Teluk Jakarta terlihat dari pola distribusi pastikel tersuspensi (TSS) dimana nilai kisaran konsentrasi partikel tersuspensi (TSS) setelah pasca reklamasi lebih besar dibandingkan pra reklamasi. Kondisi ini karena pengaruh pasokan material pelapukan dari daratan melalui run off terhalang oleh pulau reklamasi dan terhambat ke laut lepas, sehingga nilai kisaran konsentrasi partikel tersuspensi (TSS) lebih besar setelah pasca reklamasi Teluk Jakarta. Adanya pulau buatan dari proses reklamasi berpotensi meningkatkan konsentrasi partikel tersuspensi di kolom perairan yang berujung pada kemungkinan dampak terjadi sedimentasi dan pengendapan sedimen ke dasar perairan yang dapat merubah dasar perairan dan juga dapat membahayakan komunitas organisme bentik.

Logam berat merupakan elemen kimia dengan berat massa atom sebesar 5 $\mathrm{gr} / \mathrm{cm}^{3}$ (Buffle \& Vitre 1994). Penelitian ini lebih memfokuskan pada logam berat jenis $\mathrm{Cu}$ dan $\mathrm{Zn}$ Terlarut. $\mathrm{Cu}$ terlarut perairan pada saat pasca reklamasi berkisar antara 0-0,092 $\mathrm{mg} / 1$ dengan rata-rata sebesar $0,007 \mathrm{mg} / 1$ (Gambar 3c) sedangkan pada saat pra-reklamasi berkisar antara 0,001$0,005 \mathrm{mg} / 1$ dengan rata-rata sebesar 0,002 $\mathrm{mg} / 1$ (Gambar 3d). Cu terlarut perairan Teluk Jakarta berkisar 0,001-0,036 mg/1 (Ismail dan Wasilun 1986; Arifin et al. 2003; Arifin 2004; Razak 2004; Kusuma et al. 2014). Umumnya nilai konsentrasi $\mathrm{Cu}$ terlarut di perairan laut sebesar 0,008 $\mathrm{mg} / 1$ (KLHK 2004). Zn terlarut perairan pada saat pasca reklamasi berkisar antara 0-0,280 dengan rata-rata sebesar 0,023 mg/l (Gambar 3e) sedangkan pada saat pra-reklamasi berkisar antara 0,003-0,097 $\mathrm{mg} / 1$ dengan rata-rata sebesar $0,044 \mathrm{mg} / 1$ (Gambar 3f). Zn terlarut perairan Teluk Jakarta berkisar 0,001-0,097 mg/1 (Ismail dan Wasilun 1986; Williams et al. 2000; Arifin et al. 2003; Arifin 2004; Razak 2004; Hamzah dan Setiawan 2010; Kusuma et al. 2014). Umumnya nilai konsentrasi $\mathrm{Zn}$ terlarut di perairan laut sebesar $0,05 \mathrm{mg} / 1$ (KLHK 2004). Tembaga (Cu) dan seng (Zn) dalam konsentrasi yang sedikit sangat bermanfaat bagi fitoplankton tembaga $(\mathrm{Cu})$ dimana sebagai penyusun plastocyanin yang berfungsi sebagai transpor elektron dalam proses fotosintesis sedangkan seng $(\mathrm{Zn})$ berfungsi untuk membantu kerja enzim dalam transfer hidrogen saat fotosintesis dan pembentukan asam amino dan protein namun jika konsentrasi kedua logam berat ini berlebihan mampu mengakibatkan toksisitas dan kematian bagi organisme akuatik dan bioakumulasi pada sedimen dan organisme bentik. Sumber utama tembaga dan seng di Teluk Jakarta adalah dari antropogenik seperti limbah industri kabel, industri bangunan, dan aktivitas pelabuhan. Pola distribusi $\mathrm{Cu}$ Terlarut dan $\mathrm{Zn}$ Terlarut juga menggambarkan dimana nilai kisaran konsentrasi $\mathrm{Cu}$ Terlarut dan $\mathrm{Zn}$ Terlarut setelah pasca reklamasi lebih besar dibandingkan pra-reklamasi. Hal ini semakin kuat mengindikasikan pasokan limbah dari antropogenik yang mengandung logam berat dari daratan terhambat ke laut lepas karena oleh pulau reklamasi. Adanya pulau buatan dari proses reklamasi berpotensi meningkatkan konsentrasi logam berat di kolom perairan berujung pada kemungkinan dampak terjadi akumulasi logam berat di sedimen dan organisme dasar perairan dan juga dapat membahayakan komunitas organisme bentik. Kondisi pola distribusi perairan baik pada saat pasca reklamasi maupun pra-reklamasi dari menunjukkan bahwa kontribusi input pasokan material dari daratan yang dibawa dari melalui sungai atau drainase masih memegang peranan yang sangat besar di Teluk Jakarta.

Secara umum kisaran pola distribusi kualitas perairan pada saat pasca reklamasi lebih tinggi dibandingkan pada saat prereklamasi. Adanya pulau buatan dari kegiatan reklamasi berpotensi meningkatkan kisaran konsentrasi sebaran kualitas perairan. Ada pulau buatan mengakibatkan input pasokan material dari daratan yang masuk ke perairan Teluk Jakarta melalui 
aliran sungai karena terhalang oleh pulau buatan. Besarnya pasokan input material dari daratan yang terhalang oleh pulau buatan akan menumpuk dan sulit bergerak keluar sehingga mengakibatkan pola distribusi kualitas perairan terkonsentrasi di wilayah pesisir secara terus menerus dan pada akhirnya mengakibatkan konsentrasi kualitas perairan pada saat pasca reklamasi lebih tinggi dibandingkan pada saat sebelum

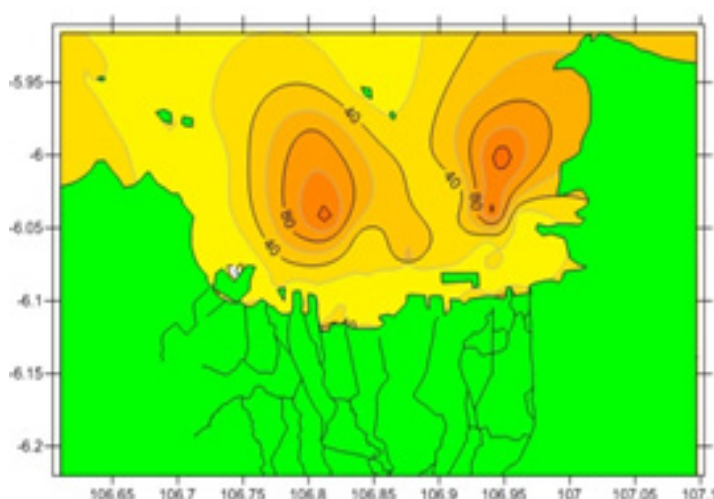

(a)

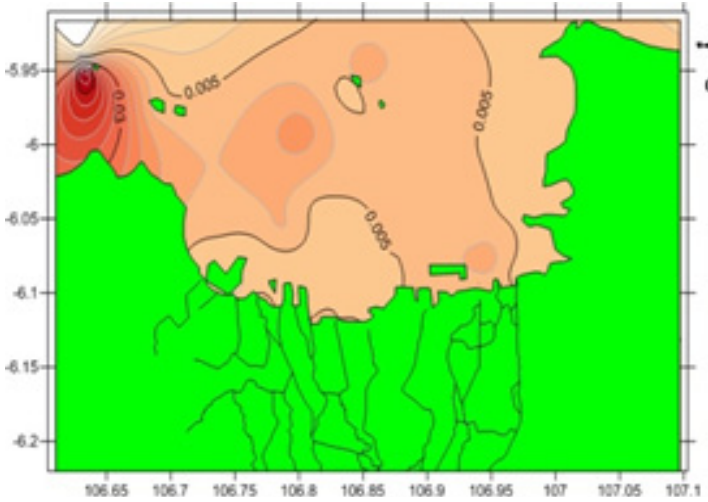

(c)

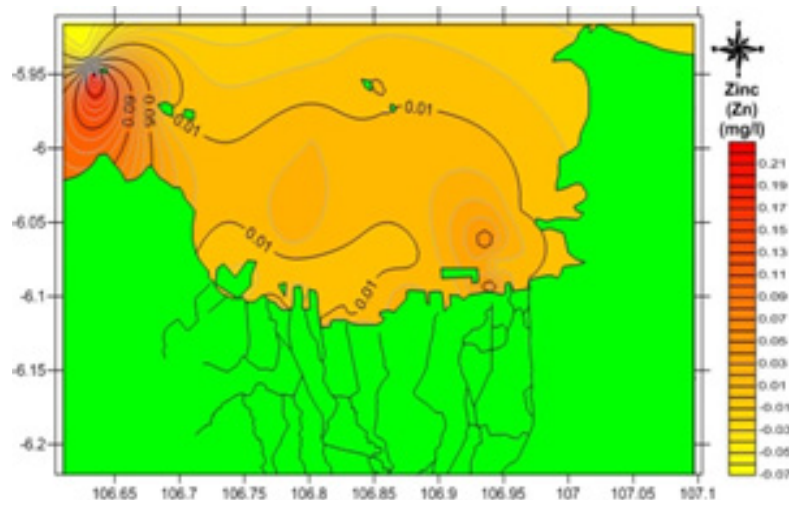

(e) adanya kegiatan reklamasi di Teluk Jakarta. Kondisi ini juga memicu kemungkinan efek pendangkalan, eutrofikasi atau pengkayaan nutrien, blooming alga, dan kematian massal serta akumulasi logam berat di sedimen dan organisme bentik. Sebaran partikel tersuspensi (TSS), Cu Terlarut dan Zn Terlarut pada saat pasca reklamasi dan pra-reklamasi di Teluk Jakarta dapat dilihat pada Gambar 3.

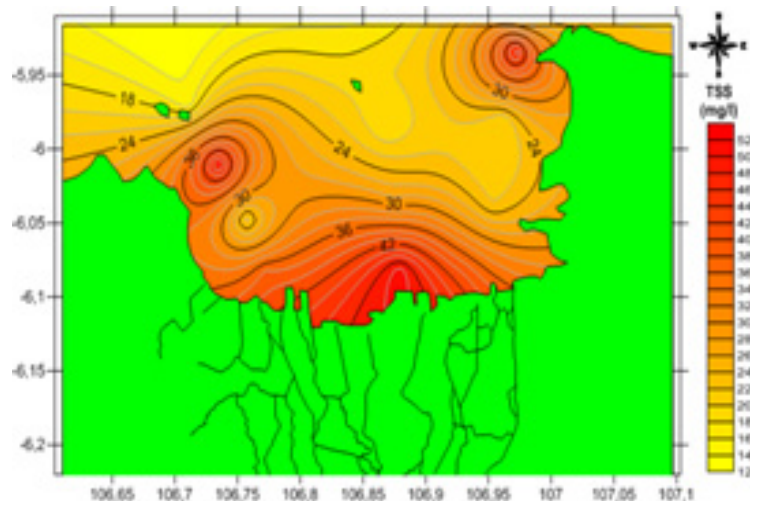

(b)

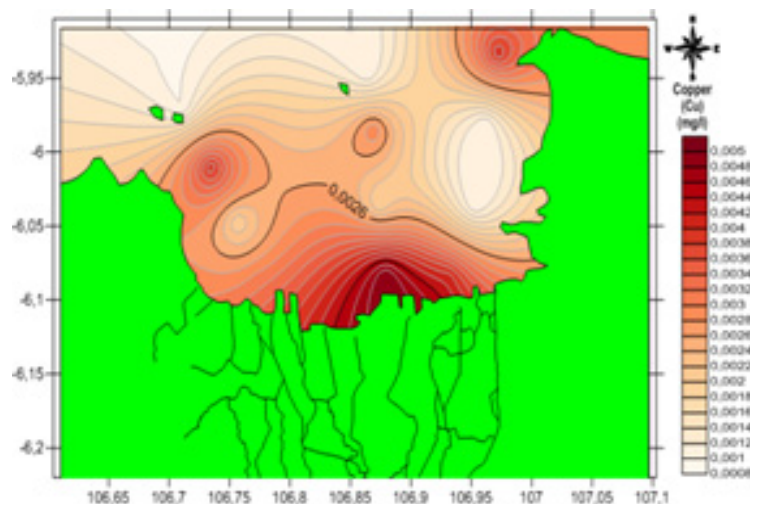

(d)

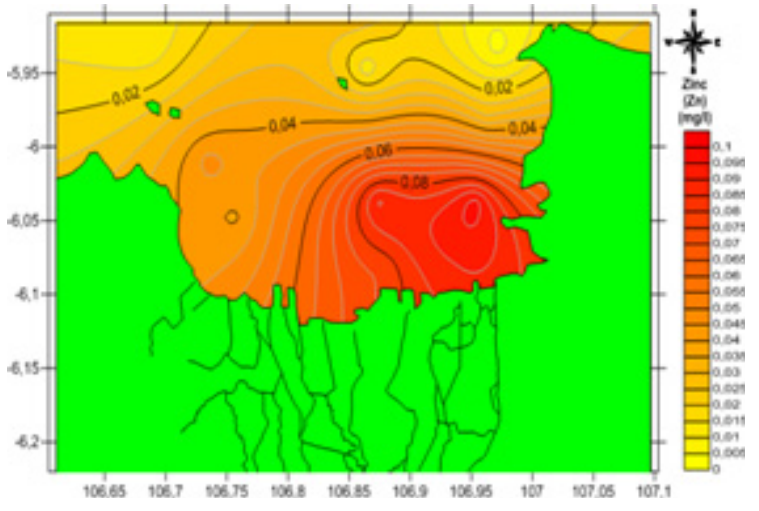

(f)

Gambar 3. Sebaran (a) partikel tersuspensi (TSS), (c) Cu terlarut, dan (e) Zn terlarut pada saat pasca reklamasi, sedangkan sebaran (b) partikel tersuspensi (TSS), (d) $\mathrm{Cu}$ terlarut, dan (f) $\mathrm{Zn}$ terlarut pada saat pre-reklamasi di Teluk Jakarta 


\section{Sirkulasi arus pasang surut perairan Teluk Jakarta}

Sirkulasi arus yang mendominasi perairan Teluk Jakarta adalah arus pasang surut. Fatoni (2011) menjelaskan rambatan pasang surut dengan komponen K1 di Laut Jawa merambat dari Timur ke Barat dengan perubahan jam 20 menuju jam 24 dengan amplitudo yang rapat di sekitar Laut Jawa sebesar $15 \mathrm{~cm}$ sampai $50 \mathrm{~cm}$. Pasang surut di Teluk Jakarta dominan besar dipengaruhi komponen K1 karena berbatasan langsung dengan Laut Jawa yang merambat berasal dari Laut Flores. Hatayama (1996) menambahkan komponen pasang surut K1 merambat dari Samudera Pasifik menuju Laut Jawa melalui 3 jalur yaitu melewati Laut Cina Selatan menuju Laut Jawa, melewati Laut Sulawesi menuju Selat Makasar kemudian berbelok ke Laut Jawa dan melewati Laut Halmahera melewati Laut Flores menuju Laut Jawa. Sirkulasi arus pasang surut pada saat pra-reklamasi Teluk Jakarta terlihat pola arus pada saat kondisi menuju pasang arus bergerak masuk ke dalam teluk dari Timur menyusuri Teluk Jakarta dan keluar melalui Barat dengan kecepatan rata-rata 0-0,02 m/s (Gambar 4a) sedangkan pada saat pasca reklamasi Teluk Jakarta dengan pola yang sama namun kecepatan ratarata yang berkurang menjadi $0-0,01 \mathrm{~m} / \mathrm{s}$ (Gambar 4b). Sirkulasi arus pasang surut pada saat pra-reklamasi Teluk Jakarta pada saat kondisi menuju surut terlihat arus berbalik arah bergerak dari Barat melewati pantai dan akhirnya keluar melalui bagian Timur dengan kecepatan rata-rata sebesar 0-0,02 m/s (Gambar 4e) sedangkan pada saat pasca reklamasi Teluk Jakarta dengan pola yang sama namun kecepatan ratarata yang berkurang menjadi $0-0,01 \mathrm{~m} / \mathrm{s}$ (Gambar 4f). Aprilia dan Pratomo (2017) mengatakan sirkulasi arus pasang surut pada saat pra-reklamasi di Teluk Jakarta pada saat kondisi pasang tertinggi berkisar 0-0,510 m/s, pada kondisi surut terendah kecepatan arus berkisar 0-0,930 m/s sedangkan sirkulasi arus pasang surut pada pasca reklamasi pada saat pasang tertinggi berkisar antara 0-0,540 m/s. Sedangkan pada saat surut terendah dengan kecepatan arus berkisar 0-0,880 m/s. Setyawan (2016) menambahkan kecepatan arus pasang surut di Teluk jakarta pada saat pra-reklamasi berkisar 0,03-0,04 m/s sedangkan pasca reklamasi berkisar 0,01-0,03 m/s. BPLHD (2014) mengatakan waktu pencucian massa air Teluk Jakarta (flushing time) dari 7 hari menjadi sekitar 14 hari akibat adanya pulau reklamasi. Di perairan yang berdekatan dengan muara sungai, perubahan pola arus pasang surut ini memiliki potensi menyebabkan pendangkalan sehingga kedalaman perairan yang berhadapan dengan pulau reklamasi akan semakin dangkal dan lebih lanjut akan berdampak pada meningkatnya laju sedimentasi. Pola sirkulasi arus pasang surut pada saat pasca reklamasi dan pra-reklamasi di Teluk Jakarta dapat dilihat pada Gambar 4.

Adanya pulau buatan dari kegiatan reklamasi mengakibatkan terjadinya perubahan pola sirkulasi dan kecepatan arus perubahan waktu pencucian. Kondisi ini membuat kecepatan pergerakan arus lebih kecil dibandingkan pada saat pasca reklamasi dibandingkan pada saat prereklamasi sehingga mengakibatkan kemampuan waktu pencucian (flushing time) polutan menjadi berkurang. Waktu pencucian (flushing time) polutan menjadi lebih lama sehingga polutan menjadi terkonsentrasi dan akumulasi di pesisir di Teluk Jakarta. Secara umum adanya pulau buatan dari aktivitas reklamasi Teluk Jakarta mengakibatkan pasokan material dari daratan yang masuk ke laut menjadi tertahan di wilayah pesisir dan mengurangi kecepatan arus sehingga terjadi penurunan kemampuan waktu pencucian dan kualitas perairan terkonsentrasi di wilayah pesisir secara terus menerus. Kondisi ini pada akhirnya mengakibatkan kisaran konsentrasi kualitas perairan pada saat pasca reklamasi lebih tinggi dibandingkan pada saat sebelum adanya kegiatan reklamasi di Teluk Jakarta. Hal ini nantinya juga dikawatirkan akan memicu kemungkinan efek pendangkalan, eutrofikasi atau pengkayaan nutrien, blooming alga, dan kematian massal serta akumulasi logam berat di sedimen dan organisme bentik. 


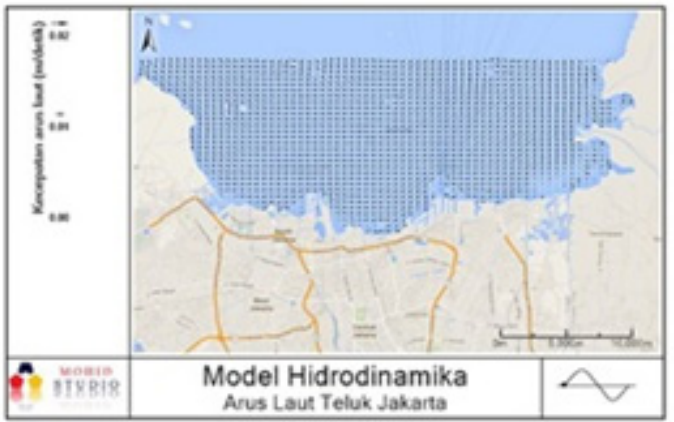

(a)

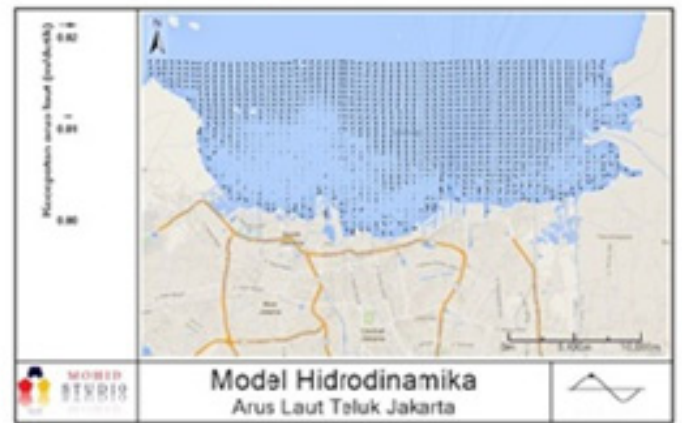

(c)

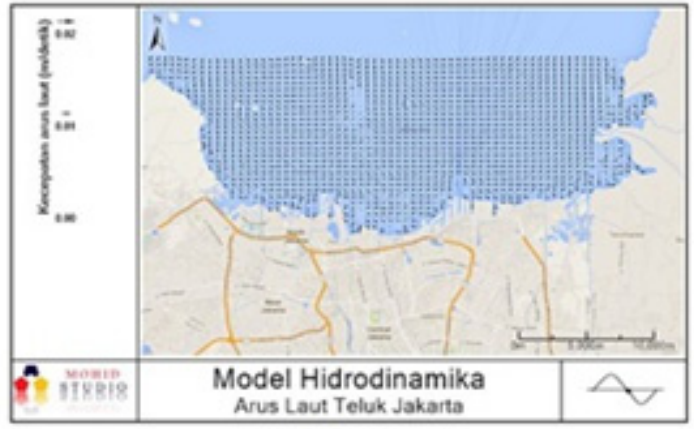

(e)

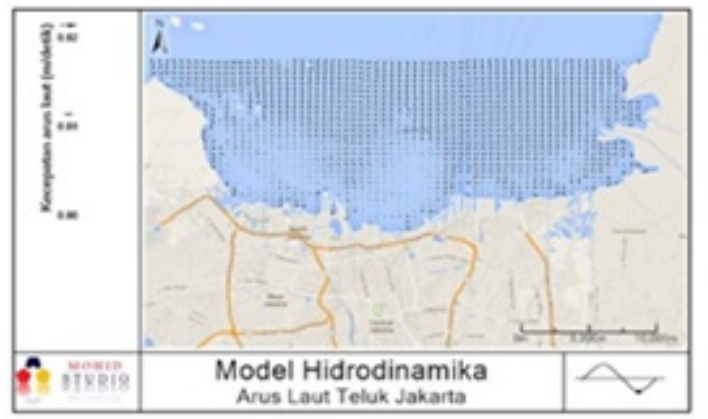

(g)

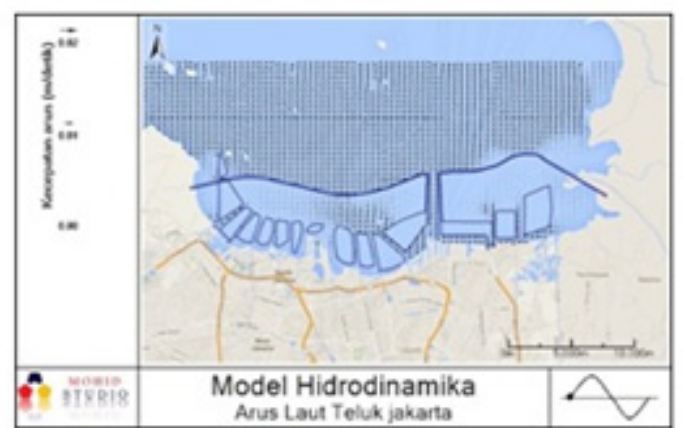

(b)

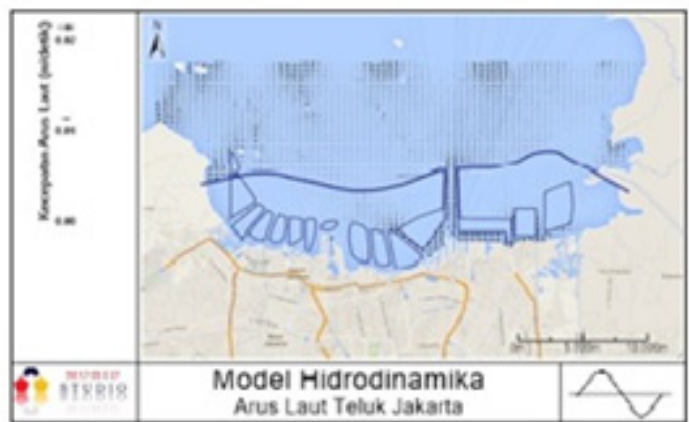

(d)

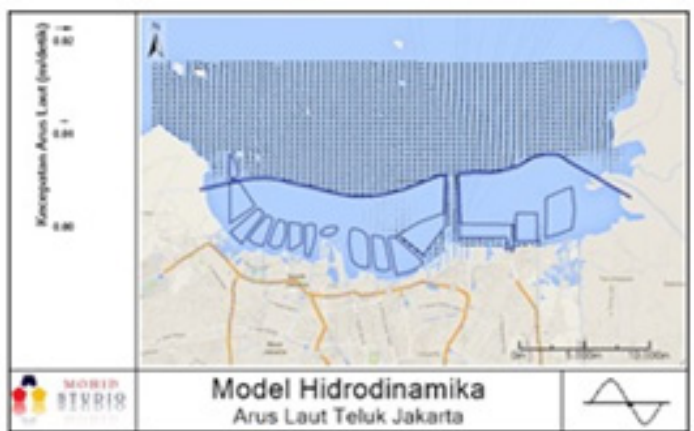

(f)

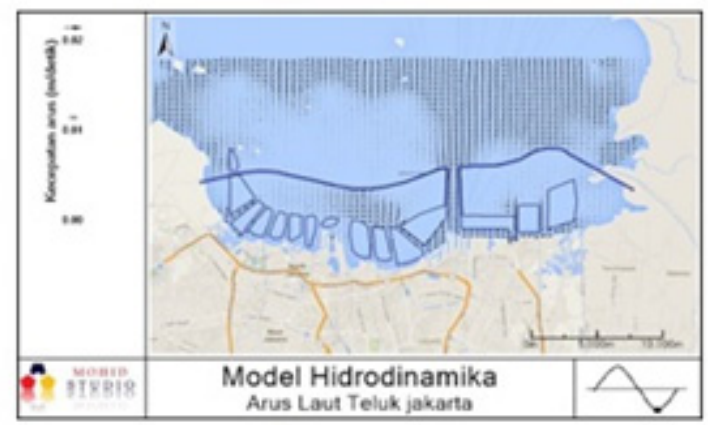

(h)

Gambar 4. Sirkulasi arus pasang surut pada saat (a) menuju pasang, (c) pasang tertinggi, (e) menuju surut, dan (g) surut terendah pada saat sebelum reklamasi di Teluk Jakarta, sedangkan (b) menuju pasang, (d) pasang tertinggi, (f) menuju surut, dan (h) surut terendah pada saat setelah reklamasi di Teluk Jakarta (Pranowo et al. 2014) 


\section{KESIMPULAN DAN SARAN}

\section{Kesimpulan}

Akibat adanya pulau buatan dari aktivitas reklamasi di Teluk Jakarta membuat pasokan material dan bahan pencemar dari daratan yang masuk ke Teluk Jakarta melalui aliran sungai menjadi tertahan di wilayah pesisir. Besarnya pasokan input material dari daratan yang terhalang oleh pulau buatan akan menumpuk dan sulit bergerak keluar secara terus menerus. Selain itu, adanya pulau buatan mengakibatkan perubahan pola distribusi dan penurunan kecepatan arus yang berujung pada penurunan kemampuan waktu pencucian (flushing time). Waktu pencucian (flushing time) polutan di Teluk Jakarta pada saat pasca reklamasi menjadi lebih lama dibandingkan pada saat prareklamasi. Hal ini mengakibatkan kisaran konsentrasi kualitas perairan seperti suhu, salinitas, derajat keasaman (pH), kekeruhan, partikel tersuspensi (TSS) dan logam terlarut pada saat pasca reklamasi lebih tinggi dibandingkan pada saat sebelum adanya kegiatan reklamasi di Teluk Jakarta. Kondisi seperti ini yang terjadi terus menerus maka dikhawatirkan terjadinya peningkatan intesitas efek pendangkalan, eutrofikasi atau pengkayaan nutrien, blooming alga, dan kematian massal serta akumulasi logam berat di sedimen dan organisme bentik.

\section{Saran}

Perlunya dilakukan penelitian yang memuat data kualitas perairan yang lebih selama satu tahun penuh yang dapat mewakili Musim Barat (Desember-Februari), Musim Peralihan I (Maret-Mei), Musim Timur (Juni-Agustus) dan Musim Peralihan II (September-Oktober) baik di Teluk Jakarta. Data yang sangat lengkap ini nantinya akan mampu menggambarkan secara detil fenomena perubahan dan perbedaan pola distribusi kualitas perairan Teluk Jakarta dari musim ke musim baik pada saat pascareklamasi maupun pada saat pra-reklamasi di Teluk Jakarta sehingga nantinya juga dapat dijadikan landasan dalam membuat kebijakan yang akurat mengenai pengelolaan wilayah pesisir di Teluk Jakarta.

\section{UCAPAN TERIMA KASIH}

Penulis menyampaikan ucapan terima kasih kepada Kepala Dinas Lingkungan Hidup DKI Jakarta, Pemerintah Provinsi DKI Jakarta dan Kepala Pusat Riset Kelautan, Badan Riset dan Sumber Daya Manusia, Kementerian Kelautan dan Perikanan serta Deputi Bidang Koordinasi SDM, Iptek, dan Budaya Maritim, Kemenko Bidang Kemaritiman.

\section{DAFTAR PUSTAKA}

APHA. 2012. Standar Methode for The Examination of Water and Waste Wayer. 22 th Edition. American Oublic Health Association. USA: Washington DC.

Ahmad F. 2012. Kandungan Senyawa Polisiklik Aromatik Hidrokarbon (PAH) di Teluk Jakarta. Ilmu Kelautan. 17(4): 199-208.

Aprilia E, Pratomo DG. 2017. Pemodelan Hidrodinamika 3-Dimensi Pola Persebaran Sedimentasi Pra dan Pasca Reklamasi Teluk Jakarta. Teknik. 6(2): 2337-3520.

Arifin Z, Susana T, Purwati P, Muchsin R, Hindarti D, Riyono S, Razak H. Matondang A, Salim E, Farida N. 2003. Ecosystem and Productivity of Jakarta Bay and it Summary Report of Competition Research. Jakarta: P20-LIPI.

Arifin Z. 2004. Trend of Coastal Pollution in Jakarta Bay. Indonesia: Its Implication for Fishery and Recreational Activities. Di dalam: Rahmawati R, Aldrian E, Hendiarti $\mathrm{N}$ dan Tejakusuma I, editor. International Workshop on Coastal Resources Explorattion and Concervation. 2008 Oktober 17-21; Jakarta, Indonesia. Jakarta (ID): BPPT. hlm 16-21.

[BPLHD] Badan Pengelolaan Lingkungan Hidup Daerah. 2010. Kondisi Lingkungan Hidup dan Kecenderungannya: Status Lingkungan Hidup Daerah Provinsi Daerah Khusus Ibukota Jakarta. Jakarta: BPLHD. 
[BPLHD] Badan Perencanaan Pembangunan Daerah Provinsi DKI Jakarta. 2014. Rencana Pembangunan Jangka Menengah Daerah Provinsi DKI 20132017. Jakarta: BPLHD.

Buffle J, Vitre RR. 1994. Chemical and Biological Regulation of Aquatic System. New York: CRC Press.

Cordova MR, Riani E. 2011. Konsentrasi Logam Berat $(\mathrm{Hg}, \mathrm{Cd}, \mathrm{Pb})$ pada Air dan Sedimen di Muara Sungai Angke Jakarta. Hidrosfir. 6(2): 107-112.

(DLH) Dinas Lingkungan Hidup Provinsi DKI Jakarta. 2018. Laporan Pengawasan Dampak Pelaksanaan Reklmasi Pantai Utara Jakarta Terhadap Lingkungan. Jakarta: Dinas Lingkungan Hidup DKI Jakarta.

Effendi H. 2003. Telaah Kualias Air. Yogyakarta: Kanisius.

Fatoni KI. 2011. Pemetaan Pasang Surut dan Pola Perambatanya di Perairan Indonesia. [Tesis]. Bogor (ID): Insitut Pertanian Bogor.

Hadikusumah. 2008. Variabilitas Suhu dan Salinitas di Perairan Cisadane. Makara Sains. 12(2): 82-88.

Hamzah F, Setiawan A. 2010. Akumulasi Logam Berat $\mathrm{Pb}, \mathrm{Cu}$, dan $\mathrm{Zn}$ di Hutan Mangrove Muara Angke, Jakarta Utara. Ilmu dan Teknologi Kelautan Tropis. 2(2): 41-52.

Ilahude AG. 1995. Sebaran suhu, Salinitas, Siqma-T, Oksigen, dan Zat Hara di Perairan Teluk Jakarta in Atlas Oseanologi Teluk Jakarta. Jakarta : P20-LIPI.

Ismail W, Wasilun. 1986. Pengamatan Pendahuluan Kualitas Perairan Kamal Muara. Perikanan Laut. 35: 89-94.

Jalius, Setiyanto DD, Sumantadinata K, Riani E, Ernawati Y. 2008. Bioakumulasi Logam Berat dan Pengaruhnya terhadap Oogenesis Kerang Hijau (Perna viridis). Akuakultur. 3(1): 001146.

Kusuma AH, Prartono T, Atmadipoera AS, Arifin T. 2014. Sebaran Logam Berat Terlarut dan Terendapkan di Perairan Teluk Jakarta pada Bulan September 2014. Teknologi Perikanan dan Kelautan. 6(1): 41-49.

[KLHK] Kementerian Lingkungan Hidup dan Kehutanan. 2004. Keputusan Menteri Lingkungan Hidup dan Kehutanan Nomor 201 Tahun 2004 tentang Kriteria Baku Mutu Air Laut Untuk Biota Laut. Jakarta: Kementerian Lingkungan Hidup dan Kehutanan.

Mezuan. 2007. Kajian Kapasitas Asimilasi Perairan Marina Teluk Jakarta [Tesis]. Bogor (ID): Institut Pertanian Bogor.

Paonganan Y, Soedharma D, Nurjaya IW, Pratono T. 2005. Sebaran Spasiotemporal Parameter dan Kimia Perairan Bokor, Pulau Payung, dan Pulau Pari, serta di Sekitar Teluk Jakarta. Oseanografi. 8(20): 21-25.

Pemda DKI. 1999. Laporan Neraca Kualitas Lingkungan Daerah DKI Jakarta. Jakarta: Pemda DKI.

Pranowo WS, Arifin T, Heriati A. 2014. Simulasi Arus Perairan Teluk Jakarta Pra dan Pasca Konstruksi Jakarta Giant Sea Wall. Poernomo A, Sulistyo B, Wirasantosa S, Brodjonegoro IS, editor. Dinamika Teluk Jakarta: Analisis Prediksi Dampak Pembangunan Tanggul Laut Jakarta (Jakarta Giant Sea Wall). Bogor (ID): IPB Press.

Prartono T, Razak H, Gunawan I. 2009. Pestisida Organoklorine di Sedimen Pesisir Muara Citarum, Teluk Jakarta: Peran Penting Fraksi Halus Sedimen Sebagai Pentrasport DDT dan Proses Diagenesanya. IImu dan Teknologi Kelautan Tropis. 1(2): 1112.

Praseno DP dan Katoro W. 1979. Laporan Akhir Penelitian Pengembangan Sumberdaya Laut dan Pencemaran Laut. Jakarta: Pusat Penelitian Oseanografi (P20) LIPI.

Prayitno HB. 2011. Kondisi Trofik Perairan Teluk Jakarta dan Potensi Terjadinya Ledakan Populasi Alga Berbahaya $\left(\mathrm{HAB}_{\mathrm{S}}\right)$. Oseanologi dan Limnologi di Indonesia. 2(37): 247-262.

Razak H. 2004. Laporan Akhir Penelitian Kondisi Lingkungan Perairan Teluk Jakarta dan Sekitarnya. Jakarta: Pusat Penelitian Oseanografi (P20) LIPI.

Setyawan A. 2016. Simulasi Model Hidrodinamika dan Dispersi Termal di Teluk Jakarta Pra dan Pasca Reklamasi 17 Pulau. Jakarta: BRSDM KP.

Sutisna. 2007. Analisis Beban Pencemaran dan Kapasitas Asimilasi Kawasan 
Perairan Pelabuhan Sunda Kelapa Jakarta [Tesis]. Bogor (ID): Institut Pertanian Bogor.

Syahdan M. 2015. Pola Spasial dan Variabilitas Temporal Data Satelit Multisensor Hubungannya dengan Distribusi Ikan Pelagis Kecil di Selat Makassar-Laut Jawa. [Tesis]. Bogor (ID): Insitut Pertanian Bogor.

Williams TM, Ress JG dan Setiapermana D. 2000. Metal and Trace Organic Compounds in Sedimen and Waters of Jakarta Bay and The Pulau Seribu Complex, Indonesia. Marine Pollution Bulletin. 40(3): 277-285.

Wiryawan B, Zulbainarni N, Sampono N. 2013. Penilaian Lingkungan dan Valuasi Ekonomi Perikanan terhadap Reklamasi "Water Front City" Teluk Jakarta. Prosiding Seminar Nasional \& Sidang Pleno ISEI XVI. 